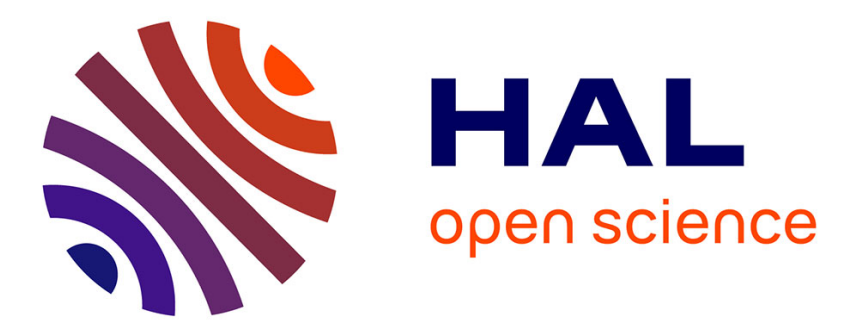

\title{
Diversity patterns of the vascular plant group Zosterophyllopsida in relation to Devonian paleogeography
}

\author{
Borja Cascales-Miñana, Brigitte Meyer-Berthaud
}

\section{To cite this version:}

Borja Cascales-Miñana, Brigitte Meyer-Berthaud. Diversity patterns of the vascular plant group Zosterophyllopsida in relation to Devonian paleogeography. Palaeogeography, Palaeoclimatology, Palaeoecology, 2015, 423, pp.53-61. 10.1016/j.palaeo.2015.01.024 . hal-01140840

HAL Id: hal-01140840 https: / hal-sde.archives-ouvertes.fr/hal-01140840

Submitted on 26 Nov 2020

HAL is a multi-disciplinary open access archive for the deposit and dissemination of scientific research documents, whether they are published or not. The documents may come from teaching and research institutions in France or abroad, or from public or private research centers.
L'archive ouverte pluridisciplinaire HAL, est destinée au dépôt et à la diffusion de documents scientifiques de niveau recherche, publiés ou non, émanant des établissements d'enseignement et de recherche français ou étrangers, des laboratoires publics ou privés. 


\title{
Diversity patterns of the vascular plant group Zosterophyllopsida in relation to Devonian paleogeography
}

\author{
Borja Cascales-Miñana $^{\mathrm{a}, \mathrm{b}, *}$, Brigitte Meyer-Berthaud ${ }^{\mathrm{a}}$ \\ a CNRS, Université de Montpellier, UMR Botanique et bioinformatique de l'architecture des plantes et des végétations (AMAP), F-34398 Montpellier Cedex 5, France \\ b PPP, Département de Géologie, Université de Liège, Allée du 6 Août, B18 Sart Tilman, B-4000 Liège, Belgium
}

\section{A R T I C L E I N F O}

\section{Article history:}

Received 11 April 2014

Received in revised form 19 January 2015

Accepted 24 January 2015

Available online 4 February 2015

\section{Keywords:}

Early tracheophytes

Boundary-crosser

Phytogeographic unit

Replacement

Sampling correction

Sea-level change

\begin{abstract}
A B S T R A C T
The Zosterophyllopsida originated in the Silurian and became prominent vascular components of Early Devonian floras worldwide. An updated dataset of zosterophyllopsids at species level is analyzed to compare the taxic composition of five putative paleophytogeographic units, Laurussia, Siberia, northwestern Gondwana, Kazakhstan and northeastern Gondwana (i.e., Australia, China and the Shan-Thai block). The high level of endemicity shown by each unit confirms the phytogeographic differentiation and the occurrence of geographical barriers preventing massive floral exchanges between the corresponding regions for the Late Silurian-Early Devonian time interval. Statistical analyses conducted on the three largest datasets, those corresponding to Laurussia, Siberia and northeastern Gondwana, indicate that the diversity dynamics of the group followed the same pattern in these regions. Almost all taxic diversity measures show that specific diversity was greatest in the middle and late Pragian. Diversity dropped significantly thereafter; however, residual diversity reveals genuine regional patterns. From this, we show that the radiation of the Zosterophyllopsida may have stopped earlier in northeastern Gondwana and Siberia than Laurussia. We propose that the onset of these extinctions resulted from the competitive replacement of the zosterophyllopsids by increasingly diversified lycopsids and basal euphyllophytes whose evolution could have been favored by external factors.
\end{abstract}

(c) 2015 Published by Elsevier B.V.

\section{Introduction}

The earliest known appearance of the zosterophylls dates back to the Ludfordian stage (Ludlow series, late Silurian) about 425 million years ago, with the earliest macro-remains found in Bathurst Island, Canadian Arctic (Kotyk et al., 2002). With their lateral sporangia arranged with varying density on the stem and a tendency for pseudomonopodial branching and rhizomatous habit (Fig. 1), the zosterophylls appear morphologically more complex than most basal tracheophytes of rhyniophyte/rhyniophytoid affinities (e.g., Cooksonia) that preceded them by about 5 million years in the fossil record (Banks, 1968; Edwards et al., 1992; Gensel, 1992; Edwards and Richardson, 2004; Gonez and Gerrienne, 2010). The diversity of the zosterophylls in terms of absolute number of genera increased in the Early Devonian. In percentage, they represented the second most diverse group in the Late Silurian and the Lochkovian; they became the dominant group of vascular plants in the Pragian and Emsian (Hao and Xue, 2013).

When Banks $(1968,1975)$ recognized the Zosterophyllophytina as a subdivision of the Tracheophyta, this group comprised a single order and a single family with six genera, Zosterophyllum Penhallow 1892,

\footnotetext{
* Corresponding author.

E-mail address: bcascales@ulg.ac.be (B. Cascales-Miñana).
}

Gosslingia Heard 1927, Crenaticaulis Edwards ex Banks \& Davis 1969, Sawdonia Hueber 1971, Rebuchia Hueber 1971 and Bathurstia Hueber 1972. At this time zosterophylls were already known to have been widely distributed, with macrofossils recorded from many localities in Europe, but also North America, Canadian Arctic, Siberia, Ukraine, South China, Vietnam and Australia (see SI in Cascales-Miñana and Meyer-Berthaud, 2014). Today, more than thirty genera are assigned to the zosterophylls. The most numerous additions have come from South China, Belgium and Great Britain (Gerrienne, 1996a,1996b; Edwards and Richardson, 2004; Hao and Xue, 2013). Except for Xinjiang in China (see Hueber and Banks, 1979; Cai et al., 1993; Wang and Hao, 1996; Xu et al., 2011) zosterophylls have not been recorded in any new area since Bank's (1975) paper. Outside South China, the Gondwanan record of zosterophylls remains very limited.

With the advent of phylogenetic systematics using large datasets, a number of proposals challenging Bank's conclusions have been made regarding the nature of the zosterophylls and their evolutionary patterns of diversification (Gensel, 1992; Kenrick and Crane, 1997; Hao and Xue, 2013). All include Sawdonia, Gosslingia and related genera in a zosterophyllopsid clade. The Zosterophyllopsida sensu Kenrick and Crane (1997) is circumscribed to taxa that have circinate growth and a two-rowed arrangement of sporangia; it includes the heterosporous genera Barinophyton and Protobarinophyton. The zosterophyllopsid 


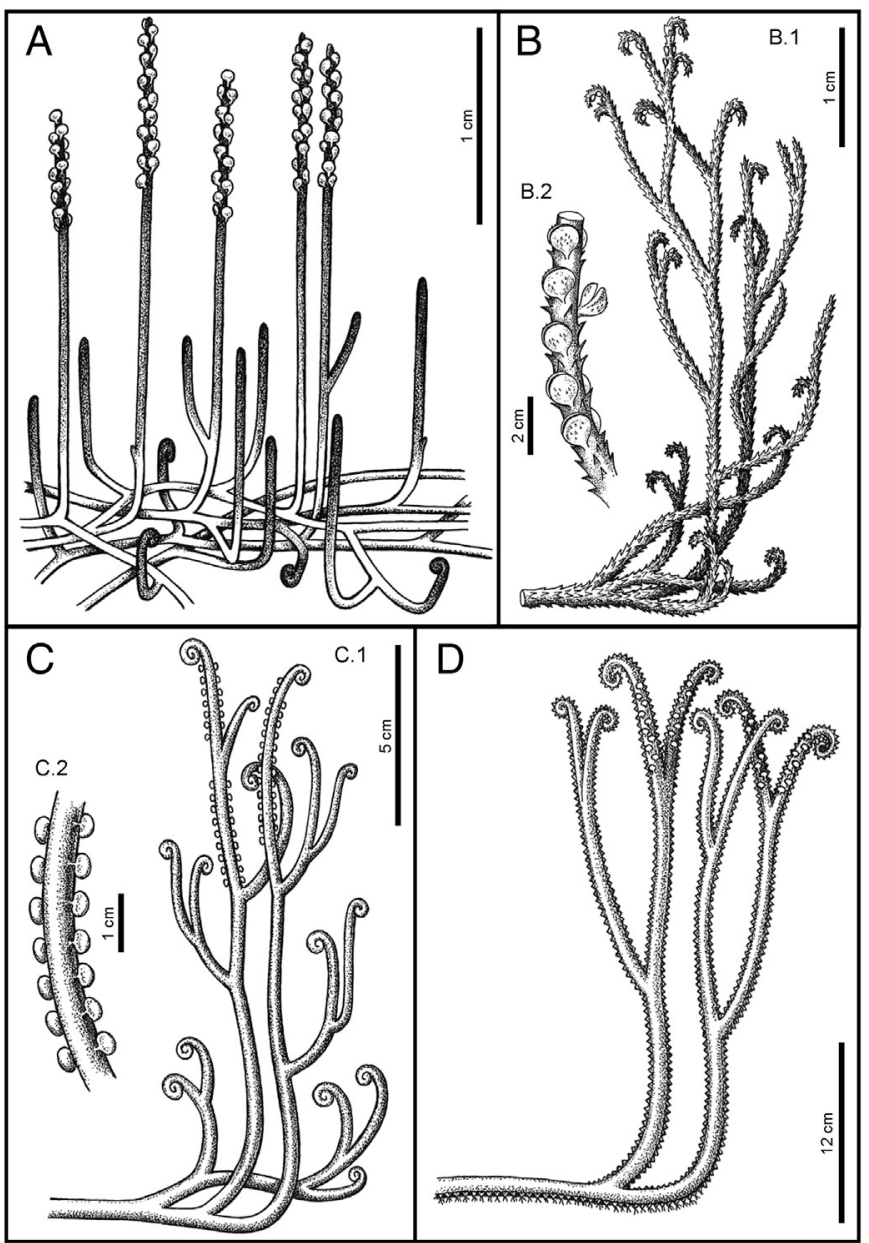

Fig. 1. Whole plant reconstructions highlighting morphological diversity within the Zosterophyllopsida. (A) Zosterophyllum myretoniamum. Upright axes branch sparsely and are naked; sporangia are arranged helically, in loose spikes. Reprinted with permission from Cleal and Thomas (1999, p. 20). (B) Sawdonia ornata. B.1: upright axes branch frequently, equally or unequally, and bear spines. B.2: sporangia are arranged in loose spikes. Reprinted with permission from Cleal and Thomas (1999, p. 20). (C) Oricilla bilinearis. C.1: upright axes branch moderately, equally or unequally, have a circinate tip, and are naked. Modified by Annette Townsend from Gensel (1982, p. 347). C.2: sporangia are auricular and arranged in 2 rows. Modified by Annette Townsend from Gensel (1982, p. 347). (D) Serrulacaulis furcatus. Upright axes branch equally, have a circinate tip, and bear deltoid emergences in two rows; horizontal axes produce rhizoids; sporangia are borne in two rows on one side of upright axis. Modified by Annette Townsend from Hueber and Banks (1979, p. 185).

clade resolved in Hao and Xue's (2013) analyses excludes all heterosporous genera; it comprises taxa with sporangia borne helically and eventually positioned terminally on the stems.

In a recent paper (Cascales-Miñana and Meyer-Berthaud, 2014), we investigated the apparent dynamics of diversification of the Zosterophyllopsida sensu Hao and Xue (2013) using diversity metrics and rates of evolution. We showed that zosterophyllopsid diversity exhibits a quick increase from the Late Silurian to the end-Pragian, followed by a marked fall ending in the Eifelian. So, during the Ludfordian-Pragian time interval, this pattern of apparent plant diversity changes (i.e., based on data taken at face value; Foote, 2001) is consistent with that predicted by Sepkoski's (1978) diversity-dependent model of diversification in its first phase. However, it does not show the equilibrium phase following the peak of diversity expected by the model in the absence of any major perturbation.

Despite the warnings of Meyen (1987) and Edwards (1990) about the limitations of the exercise, some phytogeographical patterns were recognized for early macrofloral assemblages. For the Late Silurian
Raymond et al. (2006) distinguished four phytogeographical units, north Laurussia (Bathurst Island), Kazakhstan, Australia and a large south Laurussian-northwest Gondwanan unit. Edwards and Berry (1991) proposed a possible five-partite pattern of Early Devonian floral assemblages corresponding to Australia, China, Kazakhstan, Siberia and Laurussia, the three latter ones being consistent with Petrosyan's (1967) results concerning the former Soviet Union. The statistical analysis carried out on plant traits by Raymond (1987) provided convergent results. It clearly distinguished the Australian and Kazakhstan units and, to a lesser degree, China, from a large so-called "equatorial and middle latitude unit" comprising Siberia and Laurussia. Hao and Gensel (1998) recognized the distinctiveness of the floral assemblages from South China and Australia and proposed their grouping in a northeastern Gondwanan phytogeographical unit lying between the paleoequator and $15^{\circ} \mathrm{S}$ during the Early Devonian.

If paleogeography may have had a role in shaping plant paleodiversity, no phytogeographical analyses have been dedicated to any particular early vascular plant group. Regarding the Zosterophyllopsida, Raymond et al. (2006), like Edwards and Richardson (2004) previously, recognized a preponderance of the zosterophyllopsid diversity in north Laurussia by contrast to the rhyniophytes and rhyniophytoids that flourished elsewhere. They proposed that this distinction may have corresponded to a climatic rather than purely geographic (i.e., related to paleogeographic barriers for example) control of diversity. In the Late Silurian, whereas zosterophyllopsids preferentially occupied paleoequatorial regions, rhyniophytes and rhyniophytoids may have been better adapted to the seasonal climates of the subequatorial and temperate paleolatitudes (Edwards and Richardson, 2004; Raymond et al., 2006).

Hao and Xue (2013) noted the large amount of data recently accumulated on early land plant taxa that should stimulate new phytogeographical studies. In this contribution, we provide an updated dataset at species level of the paleogeographical distribution of the Zosterophyllopsida. We test the relevance of the phytogeographical differentiation hypothesized by the authors cited above (Petrosyan, 1967; Edwards and Berry, 1991; Hao and Gensel, 1998) and we examine to what extent paleogeography may have contributed to the dynamics of the zosterophyllopsid diversity in the Early Devonian.

\section{Data}

In this paper we analyzed the species dataset corresponding to the Zosterophyllopsida sensu stricto compiled in Cascales-Miñana and Meyer-Berthaud (2014). To be consistent with the recent contributions of Hao and Xue (2013) and Xiong et al. (2013), minor modifications were included regarding the paleogeographical and stratigraphical distributions of a few taxa (Table S1). The global dataset comprises 28 genera and 93 species.

In accordance with the paleophytogeographical studies carried out thus far on early terrestrial floras, we extracted three sub-datasets corresponding to northeastern Gondwana, Laurussia and Siberia (see Introduction). The northeastern Gondwana dataset includes 39 species from Australia, South China and the Shan-Thai Block. It corresponds to a unit proposed by Hao and Gensel (1998) and supported by several Chinese paleobotanists and vertebrate paleontologists (Pan et al., 1996; Wang et al., 2010; Hao and Xue, 2013). The Laurussian dataset includes 57 species from North America and Europe. Following Edwards and Berry (1991), we analyzed the Siberian dataset (9 species) separately. The Kazakhstan dataset, which is represented by five endemic species from Kazakhstan and Xinjiang, and the northwestern Gondwana dataset, by a single species from Venezuela (Serrulacaulis cf. S. furcatus; Berry and Edwards, 1994; Xu et al., 2011), have a sample size that is too small for regional data analysis. They were considered only in the analysis of global diversity patterns. See Tables S1-S5 for details. 


\section{Methods}

Several multivariate statistical techniques (cluster analysis and ordination methods) have been used thus far to study the phytogeographic distribution of taxa and delineate phytogeographic units for the Paleozoic (e.g., Raymond et al., 1985; Raymond et al., 2006; Wellman et al., 2013). They were based on datasets representing assemblages on a worldwide basis, with a large number of taxa showing large spatial distributions. Our zosterophyllopsid dataset comprises too few widely distributed species for using such multivariate statistical methods. Our preliminary attempts using these approaches provided uninterpretable results.

As an alternative, we studied the dynamics of the Zosterophyllopsida separately for northeastern Gondwana, Laurussia and Siberia, compared them, and estimated how much each of these specific patterns contributed to the global biodiversity dynamics of the group. The methods that we used in this paper are presented below. They are detailed in Cascales-Miñana and Meyer-Berthaud (2014).

\subsection{Diversity measures}

Analyses of diversity patterns through time were conducted at species and sub-stage levels. Two diversity measures were considered, the total and boundary-crossing standing diversities (Foote, 2000; Alroy et al., 2001). Considering a time interval, the former one corresponds to the total number of species recorded within this interval whereas the latter corresponds to the number of taxa that cross its bottom boundary. The total diversity measure does not provide any information on the ratio of originations versus extinctions at any time interval. Because it includes singletons, i.e., species that originated and became extinct in the same interval, this measure is also sensitive to sampling intensity and to the duration of intervals. In comparison, boundarycrossing standing diversity minimizes such biases. Moreover, this measure indicates changes in the level of originations compared to extinctions between successive time intervals (see Bambach et al., 2004 and references therein). Indeed, comparing the boundarycrossing diversities of two successive time intervals, $t_{1}$ and $t_{2}$, is equivalent to estimating the turnover of taxa within $t_{1}$. An increase of boundary-crossing diversity between $t_{1}$ and $t_{2}$ means that the number of taxa entering $t_{2}$, i. e. leaving $t_{1}$, is greater than that entering $t_{1}$, in other words, that the number of originations exceeds the number of extinctions within $t_{1}$. On the contrary, a decrease of boundary-crossing diversity between $t_{1}$ and $t_{2}$ means that the number of extinctions exceeds the number of originations within $\mathrm{t}_{1}$.

\subsection{Sampling intensity measures}

Sampling-corrected (so-called residual) diversity curves were used to identify what portions of the total and boundary-crossing standing diversity curves were not driven by sampling intensity (e.g., Brocklehurst et al., 2013). They were obtained using Lloyd's (2012) method. Lloyd's sampling-driven model assumes that the true taxonomic richness is constant and the observed richness, a consequence of sampling. This method calculates when the taxonomic richness is greater/lower than that expected from sampling. To estimate the sampling effort, we used the minimum number of fossil assemblages (i.e., sensu Raymond and Metz, 1995) recorded for each time interval (Benton et al., 2011). The residual diversity curves were obtained using the R statistical software (R Developmental Core Team, 2013). See http://www.graemetlloyd.com/methscd.html for implementation.

\section{Results}

\subsection{Spatial distribution of zosterophyllopsids}

When examining the raw data at species level (Table 1), the most widely distributed taxon, Margophyton goldschmidtii, is found in three paleogeographical units, Laurussia, Siberia and northeastern Gondwana; this occurs in the Emsian. During the Pragian, when diversity reaches its highest values in all units, only five welldefined species are shared by two units. Three co-occur in Laurussia and Siberia (Zosterophyllum rhenanum, Sawdonia ornata, Distichophytum mucronatum), one in northeastern Gondwana and Laurussia (Zosterophyllum australianum) and one in northeastern Gondwana and Siberia (Zosterophyllum myretonianum) (Table 1). From the six zosterophyllopsid species reported from the Kazakhstan and northwestern Gondwana units, two are endemic (Sawdonia curstipa, Serrulacaulis spineus), the others being insufficiently preserved to be assigned to a taxon (Table S4).

When examining the raw data at generic level (Table 2) and when excluding Zosterophyllum, which is not a natural group, the most widely distributed genera are Distichophytum in the Pragian and Margophyton in the Emsian; both are found in three paleogeographical units only, Laurussia, Siberia and northeastern Gondwana. During the Pragian, there are three genera shared by Laurussia and northeastern Gondwana (Hicklingia, Distichophytum, Gosslingia) and two by Laurussia and Siberia (Distichophytum, Sawdonia). It is not before the Givetian that a few taxa (Sawdonia, Serrulacaulis) co-occur in any of these paleophytogeographic units and Kazakhstan or northwestern Gondwana.

\subsection{Global diversity curves}

Figs. 2A and 3A show the diversity analyses conducted on the global dataset. The total diversity and boundary-crossing curves show similar trends (Fig. 2A). The highest value of total diversity ( 44 species) occurs in the late Pragian, that of the boundary crossing diversity ( 25 species) a little earlier, in the middle Pragian. Both diversity metrics drop down to less than 20 species in the Emsian. Discrepancies between the two

Table 1

Zosterophyllopsid species shared by at least two phytogeographic units in the Devonian. See supplementary material for details.

\begin{tabular}{|c|c|c|c|c|}
\hline \multirow[t]{2}{*}{ Species } & \multicolumn{4}{|l|}{ Time units } \\
\hline & Lochkovian & Pragian & Emsian & Eifelian \\
\hline Margophyton goldschmidtii & Siberia & Siberia & $\begin{array}{l}\text { Laurussia } \\
\text { Siberia } \\
\text { NE Gondwana }\end{array}$ & - \\
\hline Zosterophyllum myretonianum & Laurussia & $\begin{array}{l}\text { Siberia } \\
\text { NE Gondwana }\end{array}$ & Laurussia & - \\
\hline Zosterophyllum rhenanum & - & $\begin{array}{l}\text { Laurussia } \\
\text { Siberia }\end{array}$ & - & - \\
\hline Zosterophyllum australianum & - & $\begin{array}{l}\text { Laurussia } \\
\text { NE Gondwana }\end{array}$ & NE Gondwana & - \\
\hline Sawdonia ornata & - & $\begin{array}{l}\text { Laurussia } \\
\text { Siberia }\end{array}$ & $\begin{array}{l}\text { Laurussia } \\
\text { Siberia }\end{array}$ & Laurussia \\
\hline Distichophytum mucronatum & - & $\begin{array}{l}\text { Laurussia } \\
\text { Siberia }\end{array}$ & Laurussia & - \\
\hline
\end{tabular}


Table 2

Zosterophyllopsid genera shared by at least two phytogeographic units in the Devonian. See supplementary material for details.

\begin{tabular}{|c|c|c|c|c|c|}
\hline \multirow[t]{2}{*}{ Genera } & \multicolumn{5}{|l|}{ Time units } \\
\hline & Lochkovian & Pragian & Emsian & Eifelian & Givetian \\
\hline Margophyton & Siberia & Siberia & $\begin{array}{l}\text { Laurussia } \\
\text { Siberia } \\
\text { NE Gondwana }\end{array}$ & - & - \\
\hline Hicklingia & - & $\begin{array}{l}\text { Laurussia } \\
\text { NE Gondwana }\end{array}$ & - & Laurussia & - \\
\hline Distichophytum & - & $\begin{array}{l}\text { Laurussia } \\
\text { Siberia } \\
\text { NE Gondwana }\end{array}$ & Laurussia & - & - \\
\hline Sawdonia & - & $\begin{array}{l}\text { Laurussia } \\
\text { Siberia }\end{array}$ & $\begin{array}{l}\text { Laurussia } \\
\text { Siberia }\end{array}$ & Laurussia & $\begin{array}{l}\text { Siberia } \\
\text { Kazakhstan }\end{array}$ \\
\hline Gosslingia & $\begin{array}{l}\text { Laurussia } \\
\text { NE Gondwana }\end{array}$ & $\begin{array}{l}\text { Laurussia } \\
\text { NE Gondwana }\end{array}$ & - & - & - \\
\hline Serrulacaulis & - & - & - & Laurussia & $\begin{array}{l}\text { Laurussia } \\
\text { NW Gondwana } \\
\text { Kazakhstan }\end{array}$ \\
\hline Oricilla & - & NE Gondwana & Laurussia & - & - \\
\hline
\end{tabular}

metrics are due to singletons. They are numerous in South China during the late Pragian and in Belgium during the early Emsian.

The boundary-crossing curve shows that originations largely exceeded extinctions in the early Pragian. Extinctions increased in the middle Pragian and became prominent in the late Pragian. A large number of taxa from the latter time interval did not cross the late Pragianearly Emsian boundary. Extinctions also exceeded originations in the late Emsian and early Eifelian.

The residual diversity curve indicates that, at a global scale, the values recorded for the middle Pragian-late Emsian interval are independent from the number of sampled assemblages (Fig. 2A). The middle and late Pragian show significant positive values of species richness. Despite the high number of singletons recorded for this time period, the late Pragian registers the highest diversity value independently from the sampling intensity. Two significant negative peaks are observed in the early and late Emsian. The most important one occurs in the early Emsian confirming the trend shown by the diversity curves (Fig. 2A).

\subsection{Laurussian diversity curves}

Figs. $2 \mathrm{~B}$ and $3 \mathrm{~B}$ show the diversity analyses conducted on the Laurussian sub-dataset. The total diversity and boundary-crossing curves show different trends between the middle Pragian and the middle Emsian (Fig. 2B). For Laurussia, the total diversity curve shows four peaks. The highest one (23 species, with a large contribution of Belgian taxa) occurs in the early Emsian. There are two smaller peaks in the early Pragian (17 species) and the late Emsian (14 species), and a minor peak in the late Eifelian ( 4 species). The boundary-crossing diversity curve, which excludes the singletons, shows its highest value in the middle Pragian (16 species), and in the middle and late Emsian (13 species). For the boundary-crossing diversity measure, the early Emsian corresponds to a time of low diversity ( 6 species) rather than a peak as observed for the total diversity.

The trends in the relative levels of originations versus extinctions shown by the boundary-crossing curve are similar to those of the global dataset.

The residual diversity curve shows three "windows" where diversity is independent of the sampling intensity (Fig. 3B). The late Pragian corresponds to a major positive peak whereas the early to middle Lochkovian and the middle Emsian to early Eifelian time intervals show low values of residual diversity. The late Emsian corresponds to the most negative excursion. Residual diversity substantially increases in the early Eifelian, after which no significant change is visible.

The combined results of the total, boundary-crossing and residual diversity curves (Fig. 2B shaded areas, Fig. 3B) indicate that, in Laurussia, zosterophyllopsid diversity was significantly low in the early and middle Lochkovian, and high in the late Pragian. A large number of species, however, became extinct in the latter time interval and did not cross the late Pragian-early Emsian boundary. Diversity decreased in the Emsian, the lowest significant value reached in the late Emsian.

\subsection{Northeastern Gondwanan diversity curves}

Figs. 2C and 3C show the diversity analyses conducted on the northeastern Gondwanan sub-dataset. Compared to the other datasets, the last record of zosterophyllopsids in northeastern Gondwana occurs early, in the early Eifelian. Despite a small difference in the early Pragian, the total diversity and boundary-crossing curves show comparable trends (Fig. 2C). The highest value of total diversity (25 species) occurs in the late Pragian and is related to the large number of singletons (13 species) documented for the Posongchong assemblages of South China. The highest value of boundary crossing diversity is much lower (8 species) and corresponds to the middle and late Pragian. Diversity decreases to 4 species in the middle and late Emsian.

The boundary-crossing curve shows that originations exceeded extinctions in the early and middle Lochkovian and in the early Pragian. Extinctions were relatively important in the late Lochkovian and the late Pragian. A relatively large number of taxa from the latter time interval did not cross the late Pragian-early Emsian boundary.

The residual diversity curve shows three "windows" where diversity is independent from the sampling intensity (Fig. 3C). A significant rise of diversity occurs between the late Lochkovian and the middle Pragian when the maximum residual value is observed. Statistically significant low values of species richness are observed during the late Pridoli and the middle and late Emsian. Interestingly, the variation of residual diversity remains within confidence limits during the late Pragian confirming that the highest value of total diversity recorded for this dataset in this time interval is artefactual and related to sampling.

The combined results of the total, boundary-crossing and residual diversity curves (Fig. 2C shaded areas, Fig. 3C) indicate that, in northeastern Gondwana, zosterophyllopsid diversity was significantly low in the late Pridoli and high from the late Lochkovian to the middle Pragian where it reached its maximum value. These results also acknowledge low diversity values in the middle and late Emsian. The highest significant level of diversity registered in northeastern Gondwana during the middle Pragian was moderate compared to that of Laurussia, in the late Pragian.

\subsection{Siberian diversity curves}

Figs. 2D and 3D show the diversity analyses conducted on the Siberian sub-dataset. The total diversity and boundary-crossing curves show 

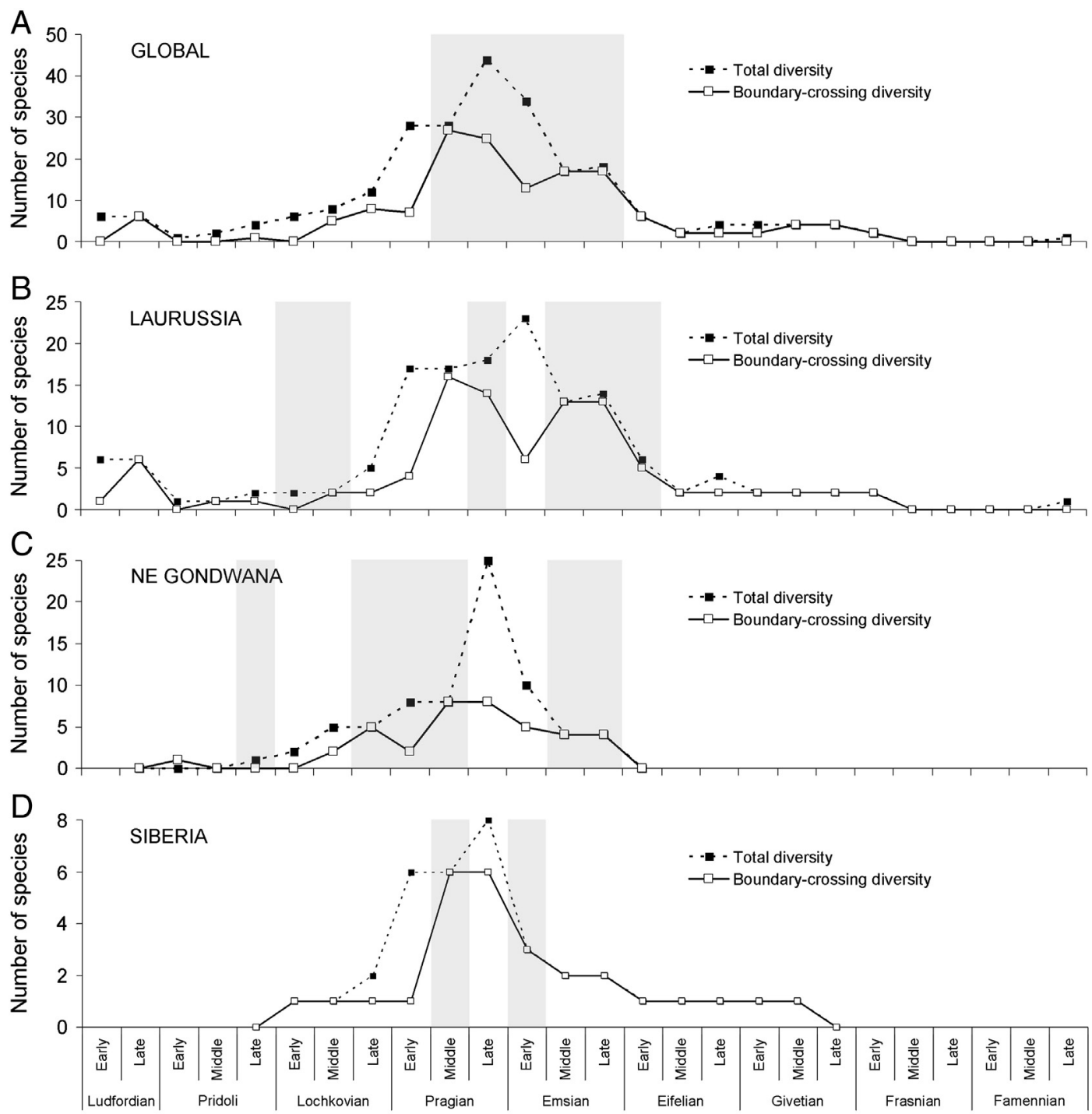

Time units

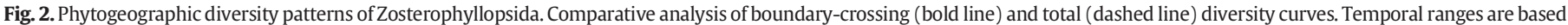

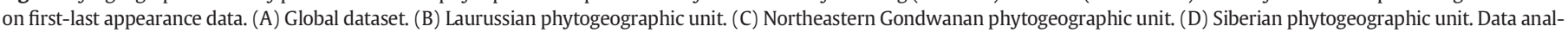
yses are conducted at species and sub-stage levels. Gray areas indicate the time intervals when diversity is independent from the number of sampled localities (see Fig. 3 ).

similar trends (Fig. 2D). The total diversity curve shows its maximum value ( 8 species) in the late Pragian, the boundary-crossing curve, in the middle and late Pragian (6 species). Both diversity curves exhibit a marked decrease of diversity in the early to middle Emsian time interval.

The boundary-crossing curve shows that originations exceeded extinctions in the early Pragian whereas a relatively large number of taxa from the late Pragian did not cross the late Pragian-early Emsian boundary.

The residual diversity curve shows only two "windows" of limited extent where diversity is independent from the sampling intensity (Fig. 3D). A significant positive peak is registered in the middle Pragian and a significant negative peak in the early Emsian. This evidence suggests that the main patterns of diversity change illustrated by the diversity curves are not biased by sampling (Fig. 2D, shaded areas).

\section{Discussion}

Paleophytogeographical studies are constrained by the intrinsic biases and limitations of the plant fossil record (e.g., incorrect identifications and assessments of systematic relationships, inaccurate dating of non-marine fossil localities, inequal sampling of all stages), by ambiguities concerning the original habitats and by uncertainties about the geographic configuration of past times (Edwards, 1990; Wnuk, 1996; Wellman et al., 2013). In this paper, we attempted to minimize sampling biases by using a set of methods successfully applied in other diversity analyses (e. g., Foote, 2000; Alroy et al., 2001; Lloyd, 2012). Another possible improvement to increase the robustness of our results would include a complete taxonomic and systematic revision of the group, a long-term task that is largely beyond the scope of this work. The taxic diversity patterns described in this paper therefore refer to apparent spatial diversity changes (diversity fluctuations calculated from fossil data taken at face value, Foote, 2001).

Our results showed that the number of species recorded prior to the Lochkovian for Laurussia or prior to the Pridoli for northeastern Gondwana, and posterior to the early Eifelian, is strongly dependent on the number of sampled localities. The Late Silurian record of zosterophylls, therefore, is unreliable for assessing the early diversity patterns of the group. The Ludfordian genera reported from Bathurst Island (Table S1) may not give a correct indication of when and where the first zosterophyllopsids originated.

The following discussion focusses on a time window that minimizes the biases related to the sampling effort. It compares the patterns 
A
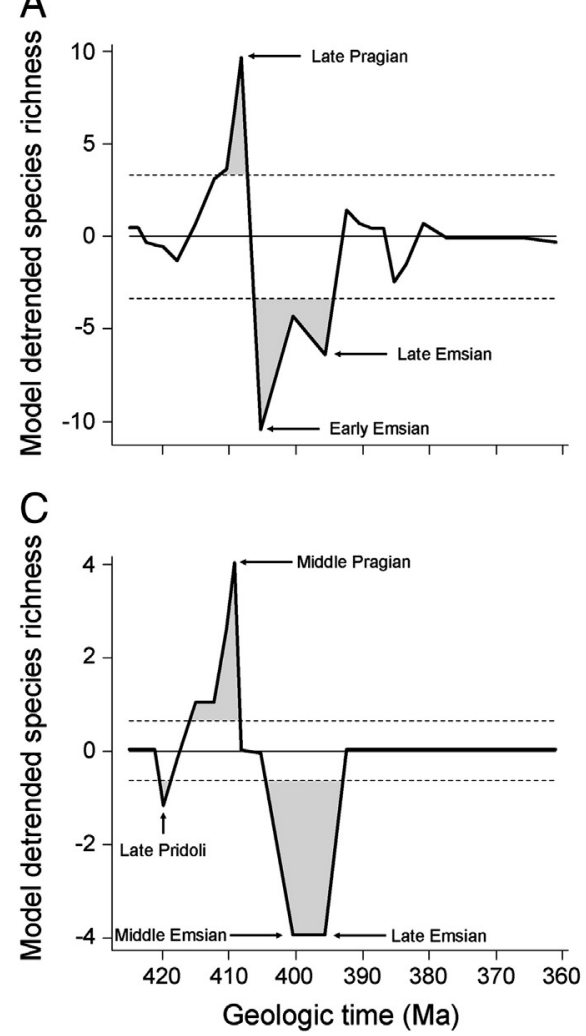

B

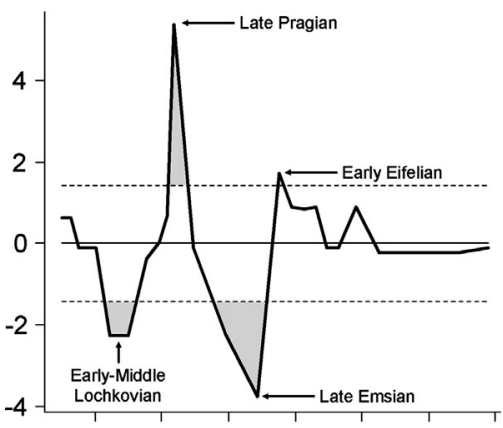

D

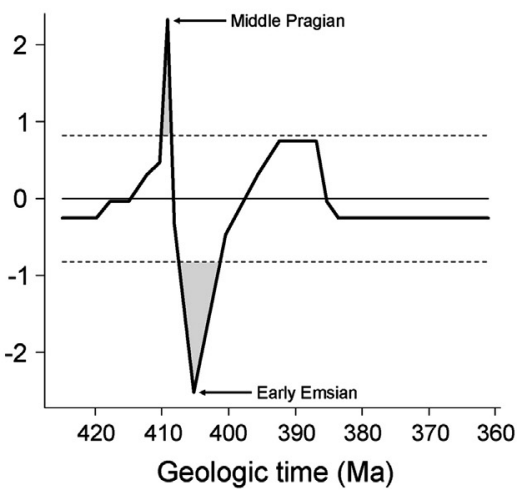

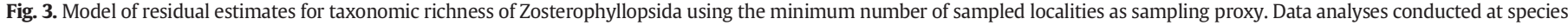

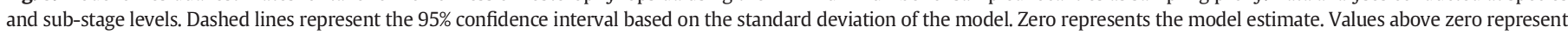

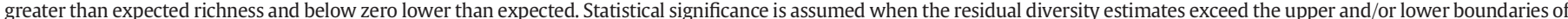

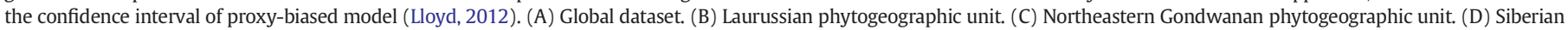
phytogeographic unit. Significant time intervals are indicated by arrows.

of zosterophyllopsid diversity of Laurussia, Siberia, northeastern Gondwana, northwestern Gondwana and Kazakhstan during the Early Devonian and examines what factors may explain their similarities and differences.

\subsection{Compared patterns of diversity changes between phytogeographic units}

The Zosterophyllopsida of Laurussia, northeastern Gondwana and Siberia show similar curves of diversity changes (Fig. 2B-D). Their specific diversity increased markedly during the Lochkovian. This phase of radiation reached a peak that, depending on the phytogeographic unit and the approach taken to measure diversity, occurred between the middle Pragian and the early Emsian (Table 3). The peak was followed by an abrupt drop of diversity ending in the Eifelian (Fig. 2; see also Cascales-Miñana and Meyer-Berthaud, 2014). For all regions, the boundary diversity curves provide evidence of a high level of extinction in the late Pragian. This similarity in the shape of the diversity curves of the three units suggests that the processes governing these changes, especially the onset of a phase of high extinction just after the phase of radiation, were similar and probably global.

As zosterophyllopsid specific diversity started to decrease, lycopsids and basal euphyllophytes showed the reverse tendency. These trends, quantified in Niklas et al.'s (1985) analysis of land plant diversification, have been confirmed since then with the description, in Laurussia and South China especially, of many new taxa of Pragian and Emsian age belonging to these latter groups (Hao and Xue, 2013, Table A4; Taylor et al., 2009). Disparity also rose significantly in the lycopsids and the basal euphyllophytes. Leaf-like organs diversified in both groups as early as the Pragian (microphylls in the lycopsids, webbed lateral branched systems in the euphyllophytes; Hao and Beck, 1993; Gerrienne et al., 2014), and a primitive type of wood evolved in the euphyllophytes (Gerrienne et al., 2011). In a context of biotic competition, new developmental innovations leading to the evolution, in the

Table 3

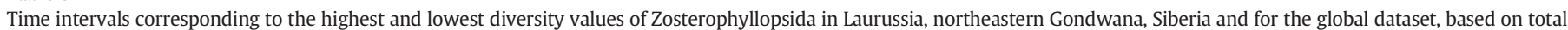
boundary-crossing and sampling corrected diversity estimates. See supplementary material for details.

\begin{tabular}{|c|c|c|c|c|c|c|}
\hline & \multicolumn{6}{|l|}{ Diversity estimates } \\
\hline & \multicolumn{3}{|l|}{ Highest diversity values } & \multicolumn{3}{|c|}{ Lowest diversity values following the positive peaks } \\
\hline & $\begin{array}{l}\text { Total (singletons and } \\
\text { sampling effect) }\end{array}$ & $\begin{array}{l}\text { Boundary crossing } \\
\text { (no singletons) }\end{array}$ & $\begin{array}{l}\text { Sampling } \\
\text { corrected }\end{array}$ & $\begin{array}{l}\text { Total (singletons and } \\
\text { sampling effect) }\end{array}$ & $\begin{array}{l}\text { Boundary crossing } \\
\text { (no singletons) }\end{array}$ & Samplingcorrected \\
\hline Laurussia & Early Emsian & Middle Pragian & Late Pragian & Middle Eifelian & Middle Eifelian & Late Emsian \\
\hline Northeastern Gondwana & Late Pragian & Middle and late Pragian & Middle Pragian & Early Eifelian & Early Eifelian & Middle and late Emsian \\
\hline Siberia & Late Pragian & Middle and late Pragian & Middle Pragian & Early Eifelian & Early Eifelian & Early Emsian \\
\hline Global & Late Pragian & Middle Pragian & Late Pragian & Early Eifelian & Early Eifelian & Early Emsian \\
\hline
\end{tabular}




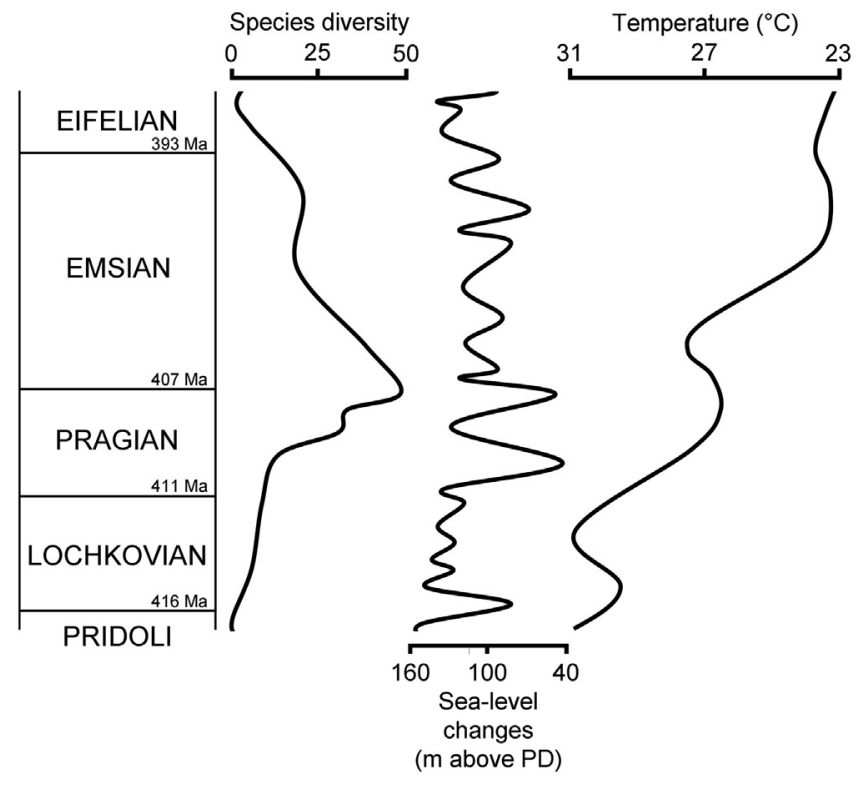

Fig. 4. Comparison between the total diversity curve of Zosterophyllopsida, the Haq and Shutter (2008, Fig. 2) sea-level curve, and the Joachimski et al.'s (2009, Fig. 7) paleotemperature curve during the Lochkovian-basal Eifelian time interval. Temporal scale adapted from Gradstein et al. (2004).

lycopsids and the euphyllophytes, of specialized taxa with increased efficiency in water transport and photosynthesis may have been disadvantageous for the zosterophyllopsids.

Climate trends for the Devonian have been reconstructed from several approaches including calculations from the oxygen isotopic composition of brachiopod shells and conodonts (Joachimski et al., 2009) and computer simulation using geochemical models (Simon et al., 2007; Le Hir et al., 2011; Godderis et al., 2014). Joachimski et al.'s (2009) paleotemperature curve calculated at a time resolution roughly comparable to that of our analyses indicates that mean sea water temperatures in tropical to subtropical paleolatitudes, where most zosterophyllopsids lived, showed a globally steady decrease from the Lochkovian to the Eifelian (Fig. 4). It is possible that from the late Pragian onwards, when the level of extinctions started to be significant, the decreasing temperatures were no longer optimal for the Zosterophyllopsida.

Sea-level was low throughout the Early Devonian. The short-term curve reconstructed by Haq and Shutter (2008), however, shows that successive sea-level changes of high magnitude occurred during the Pragian, a time interval characterized by its short duration (about 4.5 million years according to the stratigraphic chart used by Haq and Shutter; about 3.2 million years according to the 2014 chart produced by ICS - http://stratigraphy.org/index.php/ics-chart-timescale) (Fig. 4). If, as hypothesized by Hotton et al. (2001) the Zosterophyllopsida preferred stable habitats, the magnitude and frequency of the water table changes in the Pragian may have led to disturbances in both coastal environments and inland that were detrimental to the group and resulted in the first elevated ratio of extinctions versus originations at the end of this time interval.

We admit that hypotheses involving external factors such as temperature and sea-level changes to explain the highest level of extinctions at the end of the Pragian are highly conjectural, hardly testable, and not entirely satisfactory. Invoking the marked sea-level changes and the resulting disturbances that occurred throughout the Pragian as causing the extinctions of the group at the end of the interval contradicts the peak of diversity observed just before in the same time-interval. Moreover, a clade-based partitioning of early Devonian landscapes has been challenged by Kennedy et al.'s (2012) recent analysis of the distribution of plants in an Emsian locality of New Brunswick. These authors show that zosterophylls occur in the same beds as lycopsids and euphyllophytes with little evidence for ecological preferences in terms of stable versus disturbed habitats, and wetlands versus drier sites, for any of these groups. Assessing causal relationships between the diversity patterns of the Zosterophyllopsida and climatic or eustatic factors requires a deeper understanding of the ecological requirements of these plants together with a finer resolution of the spatial and temporal changes of these external factors.

If the patterns of diversity change are broadly comparable for the Laurussian, northeastern Gondwanan and Siberian paleophytogeographic units, the time occurrences of their respective highs and lows, however, differ (Table 3). With the sampling corrected approach, the highest diversity value for Laurussia occurs in the late Pragian, that for northeastern Gondwana and Siberia a little earlier, in the middle Pragian. The same difference is observed with the total diversity approach, which reveals a peak in the early Emsian for Laurussia and in the late Pragian for northeastern Gondwana and Siberia; it is less marked with the boundary crossing approach where the highest positive peak of diversity occurs in the middle Pragian for the three subunits. Following the radiation, the lowest values of diversity recorded with the sampling corrected approach are found in Siberia first (early Emsian) then northeastern Gondwana (middle Emsian) and finally Laurussia (late Emsian). A similar difference between Laurussia and the two other paleophytogeographic units is observed again when the two other approaches are used. The highest peaks of diversity for the global dataset occur in the same substages as those for Laurussia, a result that may have been anticipated when considering the relative sizes of the Laurussian, northeastern Gondwanan and Siberian subdatasets. The lowest diversity values, however, would have been more difficult to predict. Indeed, the early Emsian low value indicated by the sampling corrected approach appears relatively early and predicts a dramatic drop of diversity when considering that the same approach identifies the immediate previous substage (late Pragian) as the interval showing the highest diversity value. The early Eifelian values registered with the total and boundary crossing approaches correspond to a less spectacular decrease of diversity.

To summarize, the radiation of the Zosterophyllopsida that started in the Lochkovian reached a peak in the Pragian, earlier in northeastern Gondwana and Siberia than Laurussia. Diversity declined markedly in the Emsian to reach its lowest values before extinction in northeastern Gondwana and Siberia first. These differences provide evidence that the common pattern of diversity changes outlined for all zosterophyllopsid subdatasets showed some adjustments in relation to paleogeography. The radiation of the Zosterophyllopsida ceased earlier in northeastern Gondwana (China essentially) or Siberia than Laurussia for reasons that remain to be determined. We argued above that competitive replacement by lycopsids and basal euphyllophytes may have triggered the decrease in diversity of the zosterophylls. In this context, it is interesting to note that the earliest basal euphyllophytes with either planate or laminate lateral branched systems resembling proto-leaves were found in South China (Hao and Beck, 1993; Gerrienne et al., 2014).

\subsection{Endemic distribution of the Zosterophyllopsida in the Early Devonian}

The five paleophytogeographic units examined in this paper are characterized by a high number of endemic zosterophyll taxa. When the total observed diversity reaches its highest values, in the Pragian-Emsian time interval, the most widely distributed species (M. goldschmidtii) and genera (Margophyton, Distichophytum) are few and they are shared by three units only, Laurussia, Siberia and northeastern Gondwana (Tables 1-2).

At species level and when excluding taxa referred to as "cf." or "aff.", Laurussia and Siberia are the regions that have the highest number of species in common (Table 1). In the Pragian there are three such species (S. ornata, D. mucronatum and $Z$. rhenanum). At generic level, Laurussia shares more genera with northeastern Gondwana (i. e. 
Hicklingia, Distichophytum and Gosslingia in the Pragian) than with Siberia (Distichophytum and Sawdonia in the Pragian) (Table 2). Whatever the taxic level examined, however, the number of shared taxa is too small to make any inference about preferential levels of exchanges and proximity between paleogeographic regions.

The pronounced endemism of the Zosterophyllopsida supports the broad patterns of phytogeographical differentiation hypothesized by previous authors for the Late Silurian and the Early Devonian (Petrosyan, 1967; Raymond, 1987; Edwards and Berry, 1991; Raymond et al., 2006; Wellman et al., 2013). It indicates that the floral exchanges that resulted in the settlement of common taxa between Laurussia, Siberia, northeastern Gondwana, Kazakhstan and northwestern Gondwana were very limited and that geographic barriers may have prevented massive gene flow between these regions. This result is consistent with biogeographical analyses conducted on macrovertebrates (Young, 2010). Differences in the distribution patterns of fishes in the Late Silurian and the Early Devonian have led to the recognition of several distinctive faunal provinces. Laurussia, Siberia, Kazakhstan and Gondwana were interpreted as landmasses separated by prominent seaways that became narrower in the Middle and Late Devonian (Young, 2003; Zhao and Zhu, 2010). These studies also distinguish a Pan-Cathaysian province documenting the connection between south China, north China and Tarim (Young and Janvier, 1999), but suggesting the separation of China and Australia in the Late Silurian and the Early Devonian. Because of an insufficient number of plant records from Australia, this view, which contradicts the prevailing hypotheses in paleobotany (Hao and Gensel, 1998; Hao and Xue, 2013), was not tested in this paper.

\section{Conclusion}

The Silurian record of the Zosterophyllopsida is biased and significantly dependent on the number of sampled localities. The actual time and location of origination of the Zosterophyllopsida is uncertain.

If the available zosterophyllopsid dataset is too small, in the number of taxa or localities sampled, for identifying paleophytogeographic units, it allows acknowledgement of the taxic distinctiveness of each of the paleogeographic units hypothesized for the Early Devonian (Petrosyan, 1967; Raymond, 1987; Edwards and Berry, 1991). It recognizes that the zosterophyllopsid species of Laurussia, Siberia, northeastern Gondwana, Kazakhstan and northwestern Gondwana show little overlap. This confirms the high level of endemism shown by other organisms such as fishes in the Early Devonian (Young, 2003; Zhao and Zhu, 2010) and provides a new line of evidence for substantial marine barriers separating the corresponding landmasses at this time.

Analysis of the global dataset shows that, after a period of low diversity spanning the Late Silurian-early Lochkovian, the Zosterophyllopsida underwent a radiation that culminated in the Pragian then declined from the early Emsian until the Late Devonian. Despite their taxic differences, the specific diversities of the Zosterophyllopsida in Laurussia, northeastern Gondwana and Siberia show comparable curves, all characterized by a similar phase of origination, a high level of extinction in the late Pragian, and a marked drop of diversity thereafter. These similitudes suggest that the changes may have been driven by the same factors in the three regions.

We hypothesize that the high level of extinctions recorded in the late Pragian may have resulted from competition with the rising lycopsids and basal euphyllophytes. These groups evolved new characters such as wood and diversified leaf-like organs that led to an increase of specialized taxa with enhanced performances in fundamental functions such as photosynthesis. The decline of the zosterophyllopsids may have been precipitated by a global context of environmental changes.

Radiation of the Zosterophyllopsida stopped earlier in northeastern Gondwana (China essentially) and Siberia than Laurussia. If our hypothesis about the competitive replacement of the Zosterophyllopsida is confirmed, we anticipate an earlier burst of the lycopsids and basal euphyllophytes in the two former regions than in Laurussia.

Supplementary data to this article can be found online at http://dx. doi.org/10.1016/j.palaeo.2015.01.024.

\section{Acknowledgments}

We thank Anne-Laure Decombeix and Jean Galtier (AMAP, Montpellier) for their insightful comments and Yannick Brohard for her technical assistance in the documentation process. We also thank Annette Townsend (National Museum Wales, Cardiff) for her drawings of Oricilla and Serrulacaulis, and Chris Cleal and Barry Thomas for permission to reproduce the reconstructions of Zosterophyllum and Sawdonia from Plant Fossils: The History of Land Vegetation. We gratefully acknowledge the reviewers for their detailed comments which contributed to improve the manuscript. This research was funded by Agence Nationale de la Recherche (project \# ANR-2010-BLAN-607-02 "TERRES"). It is also a contribution to UNESCO/IGCP project 596 "Climate change and biodiversity patterns in the Mid-Paleozoic". B.C.-M. is currently supported by a Marie Curie COFUND Postdoctoral Fellowship (University of Liege - grant number: 600405).

\section{References}

Alroy, J., Marshall, C.R., Bambach, R.K., Bezusko, K., Foote, M., Fursich, F.T., Hansen, T.A. Holland, S.M., Ivany, L.C., Jablonski, D., Jacobs, D.K., Jones, D.C., Kosnik, M.A., Lidgard, S., Low, S., Miller, A.I., Novack-Gottshall, P.M., Olszewski, T.D., Patzkowsky, M.E., Raup, D.M., Roy, K., Sepkoski Jr., J.J., Sommers, M.G., Wagner, P.J., Webber, A., 2001. Effects of sampling standardization on estimates of Phanerozoic marine diversification. Proc. Natl. Acad. Sci. U. S. A. 98 (11), 6261-6266.

Bambach, R.K., Knoll, A.H., Wang, S.C., 2004. Origination, extinction, and mass depletions of marine diversity. Paleobiology 30 (4), 522-542.

Banks, H.P., 1968. The early history of land plants. In: Drake, E.T. (Ed.), Evolution and Environment. Symp. 100 th Anniversary Foundation of Peabody Museum of Natura History. Yale University Press, New Haven, pp. 73-107.

Banks, H.P., 1975. Reclassification of Psilophyta. Taxon 24 (4), 401-413.

Benton, M.J., Dunhill, A.M., Lloyd, G.T., Marx, F.G., 2011. Assessing the quality of the fossil record: insights from vertebrates. In: McGowan, A., Smith, A.B. (Eds.), Comparing the Geological and Fossil Records: Implications for Biodiversity Studies. Geol. Soc. London Spec. Pub., pp. 63-94.

Berry, C.M., Edwards, D., 1994. New data on the morphology and anatomy of the Devonian Zosterophyll Serrulacaulis Hueber and Banks from Venezuela. Rev. Palaeobot. Palynol. 81 (2-4), 141-150.

Brocklehurst, N., Kammerer, C.F., Fröbish, J., 2013. The early evolution of synapsids, and the influence of sampling on their fossil record. Paleobiology 39 (3), 470-490.

Cai, C.Y., Dou, Y., Edwards, D., 1993. New observations on a Pridoli plant assemblages from north Xinjiang, northwest China, with comments on its evolutionary and palaeogeographical significance. Geol. Mag. 130 (2), 155-170.

Cascales-Miñana, B., Meyer-Berthaud, B., 2014. Diversity dynamics of Zosterophyllopsida. Lethaia 47 (2), 205-215.

Cleal, C.J., Thomas, B.A., 1999. Plant Fossils: The History of Land Vegetation. The Boydell Press, Woodbridge (128 pp.).

Edwards, D., 1990. Constraints on Silurian and Early Devonian phytogeographic analysis based on megafossils. In: McKerrow, W.S., Scotese, C.R. (Eds.), Palaeozoic Palaeogeography and Biogeography. Geol. Soc. Mem. No. 12, pp. 233-242 (London).

Edwards, D., Berry, C.M., 1991. Silurian and Devonian. In: Cleal, C.J. (Ed.), Plant Fossils in Geological Investigation: the Palaeozoic. Ellis Horwood, New York, pp. 117-153.

Edwards, D., Richardson, J.B., 2004. Silurian and Lower Devonian plant assemblages from the Anglo-Welsh Basin: a palaeobotanical and palynological synthesis. Geol. J. 39 (3-4), 375-402.

Edwards, D., Davies, K.L., Axe, L.M., 1992. A vascular conducting strand in the early land plan Cooksonia. Nature 357, 683-685.

Foote, M., 2000. Origination and extinction components of taxonomic diversity: general problems. Paleobiology 26 (4), 74-102.

Foote, M., 2001. Inferring temporal patterns of preservation, origination, and extinction from taxonomic survivorship analysis. Paleobiology 27 (4), 602-630.

Gensel, P.G., 1982. Oricilla, a new genus referable to the zosterophyllophytes from the late Early Devonian of northern New Brunswick. Rev. Palaeobot. Palynol. 37, 345-359.

Gensel, P.G., 1992. Phylogenetic relationships of the Zosterophylls and Lycopsids: evidence from morphology, paleoecology, and cladistic methods of inference. Ann. Mo. Bot. Gard. 79 (3), 450-473.

Gerrienne, P. 1996a. A biostratigraphic method on a quantification of fossil tracheophyte characters - its application to the Lower Devonian Posongchong flora (Yunnan Province, China). Palaeobotanist 45, 194-200.

Gerrienne, P., 1996b. Lower Devonian plant remains from Marchin (northern margin of Dinant Synclinorium, Belgium). IV. Odonax borealis gen. et sp. nov. Rev. Palaeobot. Palynol. 93, 89-106.

Gerrienne, P., Gensel, P., Strullu-Derrien, C., Lardeux, H., Steemans, P., Prestianni, C., 2011. A simple type of wood in two Early Devonian plants. Science 333 (6044), 837. 
Gerrienne, P., Meyer-Berthaud, B., Yang, N., Steemans, P., Li, C.S., 2014. Planatophyton gen. nov., a Middle Devonian euphyllophyte from Xinjiang, north-west China. Rev. Palaeobot. Palynol. 208, 55-64.

Godderis, Y., Donnadieu, Y., Le Hir, G., Lefebvre, V., Nardin, E., 2014. The role of palaeogeography in the Phanerozoic history of atmospheric $\mathrm{CO}_{2}$ and climate. EarthSci. Rev. 128, 122-138

Gonez, P., Gerrienne, P., 2010. Aberlemnia caledonica gen. et comb. nov., a new name for Cooksonia caledonica Edwards 1970. Rev. Palaeobot. Palynol. 163 (1-2), 64-72

Gradstein, F.M., Ogg, J.G., Smith, A.B., Agterberg, F.P., Bleeker, W., Cooper, R.A., Davydov, V., Gibbard, P., Hinnov, L., House, M.R., Lourens, L., Luterbacher, H.-P., McArthur, J. Melchin, M.J., Robb, L.J., Shergold, J., Villeneuve, M., Wardlaw, B.R., Ali, J., Brinkhuis, H., Hilgen, F.J., Hooker, J., Howarth, R.J., Knoll, A.H., Laskar, J., Monechi, S., Powell, J., Plumb, K.A., Raffi, I., Röhl, U., Sanfilippo, A., Schmitz, B., Shackleton, N.J., Shields, G.A., Strauss, H., Van Dam, J., Veizer, J., van Kolfschoten, T., Wilson, D., 2004. A Geologic Time Scale 2004. Cambridge University Press, Cambridge (589 pp.).

Hao, S.G., Beck, C.B., 1993. Further observations on Eophyllophyton bellum from the Lower Devonian (Siegenian) of Yunnan, China. Palaeontogr. Abt. B 230, 27-41.

Hao, S.G., Gensel, P.G., 1998. Some new plant finds from the Posongchong Formation of Yunnan, and consideration of a phytogeographic similarity between South China and Australia during the Early Devonian. Sci. China 41 (1), 1-13.

Hao, S.G., Xue, J.Z., 2013. The Early Devonian Posongchong Flora of Yunnan. Science Press, Beijing (366 pp.).

Haq, B.U., Schutter, S.R., 2008. A chronology of paleozoic sea-level changes. Science 322 (5898), 64-68.

Hotton, C.L., Hueber, F.M., Griffing, D.H., Bridge, J.S., 2001. Early terrestrial plant environments: an example from the Emsian of Gaspé, Canada. In: Gensel, P., Edwards, D. (Eds.), Plant Invade the Land. Columbia University Press, New York, pp. 179-212.

Hueber, F.M., Banks, H.P., 1979. Serrulacaulis furcatus gen. et sp. nov., a new zosterophyll from the lower Upper Devonian of New York State. Rev. Palaeobot. Palynol. 28 169-189.

Joachimski, M.M., Breisig, S., Talent, J.A., Mawson, R., Gereke, M., Morrow, J.R., Day, J., Weddige, K., 2009. Devonian climate and reef evolution: insights from oxygen isotopes in apatite. Earth Planet. Sci. Lett. 284, 599-609.

Kennedy, K.L., Gensel, P., Gibling, M.R., 2012. Paleoenvironmental inference from the classic Lower Devonian plant-bearing locality of the Campbellton Formation, New Brunswick, Canada. Palaios 27, 424-438.

Kenrick, P., Crane, P.R., 1997. The Origin and Early Diversification of Land Plants: A Cladistic Study. Smithsonian Institution Press, Washington (441 pp.).

Kotyk, M.E., Basinger, J.F., Gensel, P., Freitas, J.M., 2002. Morphologically complex plan macrofossils from the Late Silurian of Arctic Canada. Am. J. Bot. 89 (6), 1004-1013.

Le Hir, G., Donnadieu, Y., Godderis, Y., Meyer-Berthaud, B., Ramstein, G., Blakey, R.C., 2011 The climate change caused by the land plant invasion in the Devonian. Earth Planet. Sci. Lett. 310 (3-4), 203-212.

Lloyd, G.T., 2012. A refined modelling approach to assess the influence of sampling on palaeobiodiversity curves: new support for declining Cretaceous dinosaur richness. Biol. Lett. 8 (1), 123-126.

Meyen, S.V., 1987. Fundamentals of Palaeobotany. Chapman and Hall, London (432 pp.)

Niklas, K.J., Tiffney, B.H., Knoll, A.H., 1985. Patterns in vascular land plant diversification: an analysis at the species level. In: Valentine, J.W. (Ed.), Phanerozoic Diversity Patterns: Profiles in Macroevolution. Princeton University Press, New Jersey, pp. 97-128.
Pan, J., Lu, L., Ji, S.A., 1996. A brief review of studies on palaeogeography of Middle Paleozoic vetebrates in China. J. SE Asian Earth Sci. 13 (3-5), 185-190.

Petrosyan, N.M., 1967. Stratigraphic importance of the Devonian flora of the USSR. In: Oswald, D.H. (Ed.), International Symposium on the Devonian System. Alberta Society of Petroleum Geologists, Calgary.

R Developmental Core Team, 2013. R: A language and environment for statistical computing. R Foundation for Statistical Computing, Vienna, Austria (http://www.R-project. org/).

Raymond, A., 1987. Paleogeographic distribution of Early Devonian plant traits. Palaios 2 (2), 113-132.

Raymond, A., Metz, C., 1995. Laurussian land plant diversity during the Silurian and Devonian: mass extinction, sampling bias, or both? Paleobiology 21, 74-91.

Raymond, A., Parker, W.C., Barrett, S.F., 1985. Early Devonian phytogeography. In: Tiffney, B.H. (Ed.), Geological Factors and the Evolution of Plants. Yale University Press, New Haven, pp. 129-168.

Raymond, A., Gensel, P., Stein, W.E., 2006. Phytogeography of Late Silurian macrofloras. Rev. Palaeobot. Palynol. 142 (3-4), 165-192.

Sepkoski Jr., J.J., 1978. A kinetic-model of phanerozoic taxonomic diversity I. Analysis of marine orders. Paleobiology 4 (3), 223-251.

Simon, L., Godderis, Y., Werner, B., Strauss, H., Joachimski, M.M., 2007. Modelling the carbon and sulfur isotope compositions of marine sediments: climate evolution during the Devonian. Chem. Geol. 246 (1-2), 19-38.

Taylor, T.N., Taylor, E.L., Krings, M., 2009. Paleobotany: The Biology and Evolution of Fossil Plants. Academic Press, Burlington (1252 pp.).

Wang, D.M., Hao, S.G., 1996. Report of Sawdonia in China - Sawdonia curstipa sp. nov. Acta Bot. Sin. 38 (4), 318-322.

Wang, W., Qu, Q.-M., Zhu, M., 2010. A brief review of the Middle Paleozoic vertebrates from Southeast Asia. Palaeoworld 19 (1-2), 27-36.

Wellman, C.H., Steemans, P., Vecoli, M., 2013. Palaeophytogeography of OrdovicianSilurian land plants. In: Harper, D.A.T., Servais, T. (Eds.), Early Palaeozoic Biogeography and Palaeogeography. Geol. Soc. London Spec. Pub., pp. 461-476.

Wnuk, C., 1996. The development of floristic provinciality during the Middle and Late Paleozoic. Rev. Palaeobot. Palynol. 90, 5-40.

Xiong, C., Wang, D.M., Wang, Q., Benton, M.J., Xue, J.Z., Meng, M., Zhao, Q., Zhang, J., 2013. Diversity dynamics of Silurian-Early Carboniferous land plants in South China. PLoS ONE 8 (9), e75706.

Xu, H., Berry, C.M., Wang, Y., 2011. Morphological study on the Devonian zosterophyll Serrulacaulis Hueber and Banks: new material and emendation. Palaeoworld 20, 322-331.

Young, G.C., 2003. North Gondwana mid-Palaeozoic connections with Euramerica and Asia: Devonian vertebrate evidence. Cour. Forsch. Inst. Senckenberg. 242, 169-185.

Young, G.C., 2010. Analytical methods in palaeobiogeography, and the role of early vertebrate studies. Palaeoworld 19, 160-173.

Young, G.C., Janvier, P., 1999. Early-middle Palaeozoic vertebrate faunas in relation to Gondwana dispersion and Asian accretion. In: Metcalfe, I., Ren, J.S., Charvet, J., Hada, S. (Eds.), Gondwana Dispersion and Asian Accretion. IGCP321 Final Results Volume. A. A. Balkema, Rotterdam, pp. 115-140.

Zhao, W.-J., Zhu, M., 2010. Siluro-Devonian vertebrate biostratigraphy and biogeography of China. Palaeoworld 19, 4-26. 